\title{
Relations between Students' Motivation, and Perceptions of the Learning Environment
}

MARKo RAdovan $^{* 1}$ AND DANiJEla MaKoveC ${ }^{2}$

$\approx$ In this research, we have examined the characteristics of university students' motivation and its connection with perceptions of the learning environment. Higher education teachers often find it challenging to decide how to organize their lectures and what instructional strategy they should use to be most effective. Therefore, we endeavoured to determine which characteristics of the learning environment best predict the motivational orientation of students and their satisfaction with the course. The survey included 120 postgraduate students of the Faculty of Arts at the University of Ljubljana. In order to measure their motivation, we employed several scales of the Motivated Strategies for Learning Questionnaire (Pintrich et al., 1991). For the purpose of this research, we created a new questionnaire for their evaluation of the learning environment. The results revealed a high correlation between the intrinsic goal orientation, self-efficacy, and control beliefs. The most important factors of the learning environment that are connected with the formation of intrinsic goal-orientation and the enjoyment of education are the perception of the usefulness of the studied topics, a feeling of autonomy, and teacher support. To an extent, these findings are supported by the findings of those authors who recommend using those methods of teaching that are in compliance with the student-centred understanding of teaching and learning.

Keywords: Learning environment, Achievement Goal orientation, Course satisfaction, Higher education didactics, University students

$1 \quad{ }^{\star}$ Corresponding Author. Faculty of Arts, University of Ljubljana, Slovenia; marko.radovan@ff.uni-lj.si

2 Teaching Assistant; Faculty of Arts, University of Ljubljana, Slovenia 


\section{Povezave med motiviranostjo študentov in zaznavanjem učnega okolja}

Marko Radovan ${ }^{*}$ In DaniJela Makovec

$\propto V$ raziskavi smo analizirali značilnosti motivacije in njeno povezanost z zaznavanjem učnega okolja. Visokošolskim učiteljem pogosto izziv predstavlja odločitev, kako organizirati svoja predavanja in katero strategijo poučevanja uporabiti. V članku smo si zato prizadevali ugotoviti, katere značilnosti učnega okolja najbolje napovedujejo motivacijsko usmerjenost študentov in njihovo zadovoljstvo. V raziskavo smo vključili 120 magistrskih študentov Filozofske fakultete Univerze v Ljubljani. Za merjenje motivacije smo uporabili več lestvic iz vprašalnika motivacijskih strategij (Pintrich et al., 1991), za vrednotenje učnega okolja pa za namen te raziskave ustvarili nov vprašalnik. Rezultati so pokazali visoko korelacijo med notranjo ciljno usmerjenostjo, samoučinkovitostjo in nadzornimi prepričanji. Najpomembnejši dejavniki učnega okolja, ki so povezani z razvojem notranje ciljne usmerjenosti, so: koristnost obravnavanih tem, občutek samostojnosti in učiteljeva podpora. Te ugotovitve so podprte $\mathrm{z}$ ugotovitvami tistih avtorjev, ki priporočajo uporabo na študenta osredinjenih metod poučevanja.

Ključne besede: učno okolje, notranja ciljna usmerjenost, zadovoljstvo z izobraževanjem, visokošolska didaktika, visokošolski študentje 


\section{Introduction}

In the previous two decades, the research conducted on achievement goals and achievement goal orientations has become highly prominent in the field of education (e.g. Ames, 1992; Dweck, 1986; Nicholls, 1984; Urdan, 2004). Moreover, certain meta-analyses have shown that this field has become predominant in the research of motivation (Austin \& Vancouver, 1996). In psychology, goals are understood as the subject, activity or phenomenon at which our action is directed and with which we satisfy our need (Locke \& Latham, 1990), whilst achievement goal orientations are the individuals' general approaches or schemes with which they undertake tasks and evaluate their achievements (Kaplan \& Maehr, 2007; Pintrich \& Schunk, 2002; Urdan, 2004). Previous research has shown that, in order to understand the students' approach to studying, it is crucial to know the reasons for their dealing with a particular task and the goals they set for themselves in the process. In this context, the authors predominantly differentiate between mastery goals (i.e. intrinsic goals for which the emphasis is placed on the development of competence) and performance goals (i.e. extrinsic goals that place an emphasis on achievements and comparisons with others). The positive effects of intrinsic goals have been demonstrated in research on a number of occasions. They express themselves in higher diligence and assiduity in performing the task (Elliot \& Church, 1997; Elliot \& McGregor, 1999; Middleton \& Midgley, 1997), increased self-efficacy (Pajares, 1997), and using advanced learning strategies (Archer, 1994). The negative consequences of extrinsic goals are mostly reflected in the use of superficial learning strategies (Elliot et al., 1999), increased perception of stress (Smith, Sinclair, \& Chapman, 2002), and self-handicapping (Urdan, 2004).

In this research, we explore the circumstances that affect the development of an individual achievement goal orientation. Researchers, have primarily discovered that they are affected by characteristics of a learning environment (e.g. Ames, 1992; Ames \& Archer, 1988; Church, Elliot, \& Gable, 2001). It is typical of these research studies that they focus on the teacher's conduct in the classroom, mainly related to two dimensions, i.e. mastery vs. performance goal structures (e.g. Ames, 1992; Kaplan, Gheen, \& Midgley, 2002; Urdan, Midgley, \& Anderman, 1998), whilst neglecting the importance of other learning environment elements that also affect their motivation. The relevant literature suggests that various elements of classroom activity, which are also related to a constructivist understanding of learning, affect achievement goal orientations (e.g. Nie \& Lau, 2010; Urdan, 2004). In this research, we will, therefore, study the connections between achievement goal orientations and those dimensions 
of the learning environment in higher education, which are considered constructivist. We will compare achievement goal orientations with other aspects of learning motivation (control beliefs, self-efficacy, and course satisfaction) and evaluations of learning environments with postgraduate students at the Faculty of Arts, University of Ljubljana, who are studying to become teachers.

\section{Achievement goal orientations}

A review of literature reveals that the research of achievement goals orientations derives predominantly from the work of Nicholls (1984) and Dweck (Dweck, 1985; Elliott \& Dweck, 1988). They define motivation as achieving goals, which refer to increasing competences and assessing competence, whilst also defining goals as purposes, which explains why an individual undertakes a particular activity. Nicholls (1984) was primarily researching how people define success in performance situations, and established that an individual can compare their achievement with their own progress, either self-reflectively (e.g. "I have learned something new", "I have performed better than the last time") or by applying some normative criterion (e.g. "I have performed better than others have"). Although Nicholls pointed out the importance of the situation in setting goals, he principally focused on establishing interpersonal differences in setting goals or motivational orientations. Being task-involved or being egoinvolved expresses differences in aspirations in achieving these performance criteria. These two orientations are supposed to be related to the perception of reasons for success, learning approaches, school evaluation and so on. Explicit differentiation between increasing competences and assessing competence is what led Dweck and Nicholls to define more precisely the two main types of performance goals: the goals that place an emphasis on management and the goals that place an emphasis on achievements.

In terms of their content, we can differentiate between two main goal orientations: 1) intrinsic goals are focused on achieving excellence, whilst with 2) extrinsic goals achievement orientation prevails. Students who set themselves intrinsic goals endeavour to improve their knowledge, performance, and competences in a particular field. The students with such goals will primarily learn to satisfy their quest for new knowledge and understanding, as well as to achieve greater competence (Ames \& Archer, 1988; Elliott \& Dweck, 1988; Nicholls, 1984). In comparison, extrinsic goals reflect an individual's motivation with good grades, competitiveness, or praise. Students with extrinsic goals are primarily focused on comparing their achievements with the achievements of others, or their abilities with the abilities of others (Ames, 1992; Elliott \& 
Dweck, 1988; Nicholls, 1984). Consequently, instead of focusing on aspiration, extrinsic goal orientation focuses more on the ability, self-evaluation, and comparison with others (Meece et al., 2006).

As regards extrinsic goals, both Dweck and Nicholls hint at the differentiation between moving towards positive and moving away from the negative evaluations of ability, yet they never explicitly define this differentiation. As a result, these two forms have been merged into a single category of extrinsic goals. Although Nicholls later added avoidance as a motivational orientation to his model, he did not relate it to extrinsic goals (i.e. achievement orientation). Instead, he proposes a new type of goals: avoidance-of-work goals (Nicholls, Patashinck, \& Nolen, 1985). These kinds of goals reflect the tendency of students to avoid schoolwork or strive to finish a learning task with the least effort. The need for the further particularization of goals has also emerged due to inconsistency of findings of various studies wherein goals and learning strategies have been explored. Wolters, Yu, and Pintrich (1996) established that students who set themselves intrinsic goals more frequently employ advanced cognitive strategies than those who set themselves extrinsic goals. By contrast, achievement orientation is mainly positively correlated with simple and superficial learning strategies (Pintrich \& De Groot, 1990). However, the influence of extrinsic goals is not always consistent, since students with extrinsic goals sometimes also employ advanced cognitive strategies and achieve good learning performance. Nearly a decade later, Elliot and Harackiewicz (1996), and Middleton and Midgley (1997) in Skaalvik (1997) established independently of each other that the characteristics and role of extrinsic goals would be better understood if they were differentiated by the components of pursuit and avoidance. Extrinsic goals were thus classified into two independent, but mutually related orientations, i.e. performance-approach goals and performance-avoidance goals. The first group of goals defines competitiveness orientation and the desire to outperform others, while the second group focuses on "avoiding failure" and a person's desire not to be perceived as incompetent. Empirical verification has confirmed the appropriateness of this tripartite differentiation of goals (Elliot \& Church, 1997; Elliot et al., 2011; Middleton \& Midgley, 1997; Wolters et al., 1996). By differentiating between performance-approach goals and performance-avoidance goals, authors began to ponder the alleged harmful effects of extrinsic goals. The prospect of extrinsic goals that are "beneficial" is what led the authors to propose a concept of multiple goals, wherein students can be simultaneously internally and extrinsically motivated in a given setting (Senko et al., 2011; Harackiewicz et al., 2002; Harackiewicz et al., 2008; Pintrich, 2000). 


\section{The learning environment}

The term "learning environment" most frequently defines the social, psychological, or psychosocial environment in which learning or, as the case may be, teaching takes place (Cleveland \& Fisher, 2014). For the most part, research has focused on the different elements of classroom context. Bronfenbrenner (1979) defines the classroom context as a microsystem, "a pattern of activities, roles and interpersonal relations experienced by the developing person in a given setting with particular physical and material characteristics" (Bronfenbrenner, 1979, p. 22), i.e. it contains elements that contribute to the understanding of the happenings in the classroom. The belief that students and teachers should be researched as a whole prevailed, but researchers have shown a tendency to isolate individual variables instead of attempting to understand the complex integration of thinking, motivation, and feelings. The authors found that teaching never directly affects learning; on the contrary, it operates through intermediary factors that include perceptions of teaching, evaluation, the climate in the classroom, the content of the school subject, structure and similar. Research has shown that the student's assessment of teaching characteristics or classroom learning environment influences a number of cognitive and affective results (Fraser, 1989; Fraser \& Fisher, 1982; Walberg, 1969). In their meta-analysis, Wang et al. (1990) established that the learning environment is one of the most important factors of learning, which affects both motivation for learning and learning achievements (Wang, Haertel, \& Walberg, 1990).

Contemporary and wider understanding of the learning environment is based on Moos' socio-ecological approach, whose aim is to explain the interrelatedness between the individual and psychosocial environments (Moos, 1974, 2002). Moos (1974) conceptualized the psychosocial environment with three dimensions that cover the majority of settings in which we find ourselves in our daily lives (e.g. at home, at workplace), as follows: 1) the relationship dimension, 2) the personal development or growth dimension, and 3 ) the system maintenance and system change dimension. The relationship dimension defines the quality and power of personal relations in a given context. This includes the level of personal engagement and cohesion, mutual assistance and cooperation between individuals in a social environment. It establishes a variety of social relations, e.g. relations between individuals, tensions in relations and teacher support, as well as their intensity (frequency, severity, and incidence). The personal development or growth dimension includes orientations with which the environment encourages personal development, growth, and promotion. In a learning environment, this is reflected in the perception of autonomy, and the 
setting of goals and demands; for example, it is determined by the students' strong orientation towards tasks, competitiveness, and the amount of research or independent action in the environment. The system maintenance and system change dimension includes rules, the clarity of expectations, surveillance mechanisms, and system responsiveness to changes. It can also reflect in the differentiation of lessons, the clarity of rules, school class organization, or the acceptance of differences. By using the instruments based on these dimensions, the authors (e.g. Fraser et al., 1982) wanted to create a tool to measure climate in the classroom in different environments (primary or secondary school, faculty, distance-learning programs). Especially in recent years, they have also wanted to support different questionnaires with constructivist dimensions of learning and teaching (Aldridge et al., 2012; Taylor et al., 1997; Walker \& Fraser, 2005). Research results have shown that the dimensions, such as Authentic Learning, Cohesiveness, Task Orientation, Rule Clarity, Satisfaction, and Teacher Support are positively related to motivation and performance of students and reflect what are now known as "constructivist learning environments" (Herrington, Reeves, \& Oliver, 2014; Loyens \& Gijbels, 2008; Walker \& Fraser, 2005).

With this term, researchers have attempted to emphasize teaching strategies that build on dialogue, collaboration, authentic tasks, and active construction of knowledge. According to Cunningham (1992), the objectivistic view of learning is depicted as the process of acquisition and remembering. In contrast, the constructivist view of learning is more accurately described as the process of knowledge construction. Therefore, active collaboration in learning tasks and referring to prior knowledge are viewed as two fundamental processes that enable students to construct new knowledge. Most constructivists would also agree that learning in authentic, real-life situations is most effective (Herrington, Reeves, \& Oliver, 2014; Loyens \& Gijbels, 2008).

Two major research models were developed to determine the connectedness between learning environment and goal orientation: TARGET (Ames, 1992) and PALS (Midgley et al., 2000).

Ames (1992) developed the TARGET system to research the main aspects of teaching that encourage the development of mastery or performance orientation in the classroom. The TARGET system focuses on instructional strategies related to task assignments $(\mathrm{T})$, authority relations (A), recognition systems $(R)$, grouping procedures $(G)$, evaluation practices $(E)$, and the use of time (T). Greene, Miller, and Crowson (2004) tested this model by examining the influence of students' perceptions of classroom structure (tasks, support of autonomy, management, and evaluation) on self-efficacy, instrumentality of classroom work and extrinsic goal orientation in the classroom environment. 
The results of analysis have confirmed the assumptions that perceptions of climate in the classroom play an important part in student motivation. Although certain previous research studies have confirmed the influence of the perceptions of the climate in the classroom on the setting of goals and self-efficacy, their findings were the first to support the line of argument that when students assess learning in the classroom as being relevant and interesting, this affects their positive assessment of learning in the future.

Midgley et al. (2000) developed a questionnaire entitled "The Patterns of Adaptive Learning Survey" (PALS), which has been often used to assess students' perceptions of predominant classroom goal structures, as well as for measuring an individual's goal orientation. By using this instrument, Urdan and Midgley (2003) examined changes in the perceived classroom goal structures when students were promoted to the next year of study. In cases in which students perceived a higher emphasis on mastery goals in the new class, they reported more positive influences, an increased sense of self-efficacy and better learning achievements (Urdan \& Midgley, 2003). If the situation was the opposite, their learning motivation, and learning performance declined.

\section{Purpose of the present study}

To date, research on the influence of learning context on the formation of goal orientations and other factors of learning motivation has primarily focused on classroom settings, specifically on the characteristics of teaching tasks, assessment, and instructional strategies. We believe that goal orientation is among the most important factors of motivation. The first and most important reason is that goal orientation directly influences many important aspects of student motivation. For example, it is more likely that students with intrinsic goal orientation will have higher self-efficacy, use more complex cognitive learning strategies, be meta-cognitively more active, and achieve better learning outcomes. Previous research shows that goals direct, or at least mediate, the entire process of self-regulation of learning, wherein the use of strategies is only one of the aspects.

Knowing goal orientations and understanding of specific classroom practices is at the core of our research. A number of reviews have been carried out in order to document the different ways in which the classroom and school environment affect the formation of a particular goal orientation (e.g. Ames, 1992; Church et al., 2001; Nie \& Lau, 2010; Urdan, 2004). In fact, the psychology of motivation has always been set into a certain context of operation. In order to understand the perception of the learning environment and the influence on 
the processes of development of intrinsic motivation, we should also highlight the contribution of Deci and Ryan (1985). They have carried out many studies in which they endeavoured to determine how differently designed environments (and educational materials) affect the development of motivation (Deci, Koestner, \& Ryan, 2001; Mažgon \& Štefanc, 2012). Deci et al. (2001) have established that three factors are crucial (i.e. autonomy, competence, and relatedness) and positively affect the development or maintenance of an individual's intrinsic motivation.

Less prominent in motivation research are studies that explore motivation in terms of a broader understanding of the learning environment, including the dimensions described by Moss, Fraser and other authors. Research in this field has also been more focused on the samples of primary and secondary education, but fewer studies have examined this topic within the framework of university education. The main research questions of this study are therefore:

1. How are the perceptions of learning environment connected to students' motivation?

2. Which aspects of learning environment and motivation predict students' satisfaction with the course?

\section{Method}

\section{Participants and procedure}

The survey was conducted between November and December 2014, and included students who were enrolled in the first year of master studies at the Faculty of Arts at the University of Ljubljana. The sample consisted of 120 students (102 female, 17 male, 1 did not reveal his or her gender) who study in different programs, but are also participating in the common teaching module. This means that than $80 \%$ of all the students in this module were included in the research. Students from foreign language (e.g. English and German Language and Literature), Slovenian, and Comparative Literature study programs prevailed with $76.7 \%$ of the whole sample. Females were also predominant in the sample (86\%), which accurately reflects the actual participants in the study programs. Students respondents were 21 to 32 years old $(M=23.3 ; S D=1.75)$. The age category 22 to 25 years represents more than $80 \%$ of all students in the research; only 9 students were older than 25 years. 


\section{Measures}

\section{Characteristics of motivation}

In order to establish the connection between motivation and perception of the learning environment, we employed motivational scales from the Motivated Strategies for Learning Questionnaire (MSLQ) (Pintrich, Smith, Garcia, \& McKeachie, 1991), which is based on a social-cognitive approach to motivation and learning characterized by stressing the interconnection of the cognitive and emotional components of learning. In the first part of the questionnaire, 20 items was used from the MSLQ, specifically from the "Intrinsic goal-orientation" and "Extrinsic goal-orientation", "Self-efficacy" and "Control beliefs" scales. The respondents replied to the five-point Likert scale questionnaire with the following answer possibilities: 1 - Definitely not true of me, 2 - Mostly not true of me, 3 - Sometimes true and sometimes not true of me, 4 - Mostly true of me, 5 - Definitely true of me. A five-point scale instead of the original seven-point scale was used to unify scales across the questionnaire.

To identify the underlying structure of motivational scales, we performed several factor analysis. First, we analysed the principal components procedure in order to assess the number of factors. The preliminary results and Cattell's scree test showed there were seven components whose eigenvalues were greater than 1 . Since an additional analysis of this table with component weights indicated the existence of four dimensions, we proceeded by carrying out a factor analysis with the principal axis method with four factors. Since items were moderately correlated, orthogonal rotation was chosen (Tabachnick \& Fidell, 2013). The Bartlett spherical test was highly significant $(p<0.001)$, whilst the Kaiser-Meyer-Olkin measure of sampling adequacy, although appropriate, was statistically insignificant $(\mathrm{KMO}=0.75)$. Together, these four factors explain $43 \%$ of the variance; in terms of content, they correspond to the theoretical expectations of the scale. With regard to the described procedure, we formed four composite motivational variables: Self-efficacy ( 5 items; explains $22 \%$ of the variance); Intrinsic goal-orientation ( 5 items; $10 \%$ of the variance); Control beliefs ( 3 items; $6 \%$ of the variance); Extrinsic goal-orientation ( 3 items; $5 \%$ of the variance).

\section{Evaluation of the learning environment}

In addition to the scales from Motivated Strategies for Learning Questionnaire, we also used the Evaluation of the Learning Environment Questionnaire. The questionnaire, developed especially for this survey, is based on Moos' (1974) conceptualization of the learning environment, similar to many other 
questionnaires that were developed mainly for the use in primary or secondary education. However, the latter instruments are inappropriate for assessing the learning environment in higher education. In this part of the questionnaire, 42 items were formed, representing the main dimensions of the learning environment: teacher support, student interaction, authentic learning, autonomy, and personal relevance. The respondents assessed their perceptions of learning environment on the course level by using the five-point Likert scale, which represented the frequency of individual "events" in lectures. The following answers were possible: 1 - Never, 2 - Seldom, 3 - Sometimes, 4 - Often, 5 - Always. The number of components was first evaluated with the principal component analysis, and the results of this analysis showed six appropriate dimensions. We employed the Varimax rotation with the principal axis method. The solution with four factors $(\mathrm{KMO}=0.84$, Bartlett spherical test $p<0.001)$ proved to be the most appropriate. Together, these factors explain $46 \%$ of the variance. We formed four composite variables: Authentic learning (eight items; explains $31 \%$ of the variance; e.g. "In this course, we deal with real situations"); Teacher support (six items; $6 \%$ of the variance; e.g. "In this course, the teacher encourages my active participation"); Student interaction (six items; explains $5 \%$ of the variance; e.g. "In this course, students collaborate with each other") and Autonomy (three items; explains $4 \%$ of the variance; e.g. "In this course, I can study at a time that is most convenient for me"). Seven items that achieved loadings under 0.45 (20\% of variance) were excluded from further analysis. Factor loadings of the "Evaluation of Learning Environment Scale" are shown in Table 1.

Table 1. Factor Loadings for the Evaluation of Learning Environment Scale

\begin{tabular}{lcccc}
\hline & \multicolumn{3}{c}{ Factor loading } \\
\cline { 2 - 4 } Item & $\begin{array}{c}\text { Authentic } \\
\text { learning }\end{array}$ & $\begin{array}{c}\text { Teacher } \\
\text { support }\end{array}$ & $\begin{array}{c}\text { Student interaction } \\
\text { and collaboration }\end{array}$ & $\begin{array}{c}\text { Students } \\
\text { autonomy }\end{array}$ \\
\hline AUTH 84 & 0.75 & & \\
AUTH 92 & 0.66 & & \\
AUTH 94 & 0.63 & & \\
AUTH 82 & 0.60 & & \\
AUTH 106 & 0.57 & & \\
AUTH 87 & 0.53 & & \\
AUTH 108 & 0.52 & & \\
AUTH 79 & 0.51 & & \\
TEACHS 99 & & & \\
\hline
\end{tabular}




\begin{tabular}{|c|c|c|c|c|}
\hline \multirow{2}{*}{$\begin{array}{l}\text { TEACHS } 93 \\
\text { TEACHS } 104\end{array}$} & & \multicolumn{2}{|l|}{0.69} & \\
\hline & & 0.68 & & \\
\hline TEACHS 76 & & 0.53 & & \\
\hline TEACHS 72 & & 0.48 & & \\
\hline TEACHS 95 & & 0.47 & & \\
\hline STUDINT 109 & & & 0.86 & \\
\hline STUDINT 107 & & & 0.75 & \\
\hline STUDINT 71 & & & 0.58 & \\
\hline STUDINT 89 & & & 0.53 & \\
\hline STUDINT 83 & & & 0.51 & \\
\hline STUDINT 112 & & & 0.45 & \\
\hline AUTON 97 & & & & 0.78 \\
\hline AUTON 100 & & & & 0.76 \\
\hline AUTON 78 & & & & 0.55 \\
\hline$\%$ Variance & 31.42 & 6.22 & 5.09 & 3.76 \\
\hline
\end{tabular}

\section{Course satisfaction}

We also used the "Course satisfaction" scale in order to obtain data on the interconnection of psychosocial characteristics of the learning environment and enjoyment of education. The scale comprises nine items, which were adapted from the Test of Science-Related Attitudes (TOSRA) (Fraser, 1981). We used the same categories of assessment (Always, Often, Sometimes, Seldom, and Never) as with the learning environment scales.

\section{Data analyses}

The psychometric characteristics of the instruments were determined with the exploratory factor analysis (latent structure of questionnaires) and Cronbach's a coefficient (to establish internal consistency). In order to answer our research questions, we employed different bivariate and multivariate analyses: to establish the connection between individual dimensions, the bivariate correlation analysis was used; to understand the predictive value of independent variables on dependent variables, the multivariate linear regression method was used. 


\section{Results}

\section{Descriptive statistics}

Initially, we shall examine the descriptive statistics used for the learning motivation and learning environment scales. Table 2 shows means, standard deviations, Cronbach's a coefficient of internal consistency, and the number of items in the scale. The means show that the respondents assessed all items relatively highly (on a five-point scale). All means are above 3 , and the results show that items from perceived autonomy and authentic learning scales were assessed the highest, whilst items related to extrinsic goals-orientation and student interaction were assessed the lowest.

Table 2. Means, Standard Deviations, Alphas, and Number of Items for Motivational and Learning Environment Scales

\begin{tabular}{lllll}
\hline Variable & $M$ & $S D$ & $\alpha$ & $N_{\text {items }}$ \\
\hline Self-efficacy & 3.43 & .72 & .79 & 5 \\
Intrinsic goal-orientation & 3.77 & .72 & .69 & 4 \\
Control beliefs & 3.97 & .72 & .58 & 3 \\
Extrinsic goal-orientation & 3.24 & .84 & .62 & 3 \\
Course satisfaction & 3.44 & .82 & .90 & 9 \\
Student interaction & 3.21 & .12 & .85 & 7 \\
Authentic learning & 3.99 & .38 & .88 & 9 \\
Teacher support & 3.69 & .93 & .82 & 6 \\
Autonomy & 4.00 & .38 & .75 & 3 \\
\hline
\end{tabular}

The analysis of standard deviation values shows that the assessments differ the most with items from the Teacher support $(S D=0.93)$ and Extrinsic goal-orientation scales $(S D=0.84)$, although the average of each of these scales is not among the highest. The standard deviations are the lowest in the perceptions of students in relation to their interactions in class $(S D=0.12)$. The coefficients of reliability are between 0.58 and 0.90 , which range between poor to very good according to DeVellis (2003). The cause of low reliability of Control beliefs and Extrinsic goal-orientation scales is most likely the low number of items in these scales. 


\section{The connection between motivational variables and dimensions of psychosocial environment}

Table 3 shows correlations between the motivational, the learning environment and course satisfaction scales. Correlational connections are mostly positive and their effect sizes range between small and large (Cohen, 1988, pp. 79-81).

Table 3. Pearson's Coefficient of Correlation between Motivational Strategies, Perception of the Learning Environment and Course Satisfaction

\begin{tabular}{|c|c|c|c|c|c|c|c|c|c|}
\hline & 1 & 2 & 3 & 4 & 5 & 6 & 7 & 8 & 9 \\
\hline 1. Self-efficacy & - & & & & & & & & \\
\hline 2. Intrinsic goal-orientation & $.32 \cdots$ & - & & & & & & & \\
\hline 3. Control beliefs & $.47^{\cdots}$ & $.21^{*}$ & - & & & & & & \\
\hline 4. Extrinsic goal-orientation & .06 & .16 & -.03 & - & & & & & \\
\hline 5. Course satisfaction & $.20^{\circ}$ & $.45^{\cdots *}$ & $.24^{*}$ & -.07 & - & & & & \\
\hline 6. Student interaction & .15 & $.51^{\cdots}$ & .02 & .24 & $.31^{* *}$ & - & & & \\
\hline 7. Authentic learning & .17 & $.60^{\cdots \cdots}$ & .17 & .09 & $.57^{\cdots *}$ & $.62 \cdots$ & - & & \\
\hline 8. Teacher support & .17 & $.45^{\cdots *}$ & .13 & .01 & $.57^{\cdots}$ & $.53^{\cdots}$ & $.60^{\cdots}$ & - & \\
\hline 9. Autonomy & $.21^{*}$ & $.33^{\cdots}$ & .15 & .09 & .07 & $.30 \cdots$ & $.18^{\circ}$ & $.20^{*}$ & - \\
\hline
\end{tabular}

Note: ${ }^{*} p<.05{ }^{* *} p<.01,{ }^{* * *} p<.001$.

Self-efficacy is positively correlated to intrinsic goal orientation $(r=$ $0.32)$ and control beliefs $(r=0.47)$, and there is no correlation with extrinsic goal orientation. Students with high self-efficacy beliefs are also more prone to feel that they can control their learning and motivation. They are also more motivated to master their learning and are not motivated in comparison with others. We also find low correlation between self-efficacy and course satisfaction $(r$ $=0.20)$ and autonomy scales $(r=0.21)$. There are numerous strong correlations between intrinsic goal orientation and other scales.

The highest correlations are between intrinsic goals and authentic learning $(r=0.60)$ and student interaction scales $(r=0.51)$. Students with intrinsic goal orientation during their studies see their courses as being tightly connected to real-life examples and can see the connection between theoretical problems in the course and the practical problems that they will face on the job. Results also show moderately high correlations between intrinsic goal orientation and teacher support $(r=0.45)$. This means that goal orientation that focuses more 
on mastery is also correlated to perceived teacher support, his/her feedback, incentives, and communication.

Correlation with perceived autonomy $(r=0.33)$ is also expected, which shows a relationship between active student participation and control, his or her learning, and the development of intrinsic motivation. Lastly, intrinsic goals are also moderately correlated with enjoyment that students feel in class $(r=0.45)$. The course satisfaction scale is positively correlated with almost all learning environment scales. The highest are correlations with authentic learning and teacher support scales (both $r=0.57$ ). This shows us that students are mostly enjoying classes where they can apply new knowledge to real-life situations and where their progress in learning is supported by teachers. Also important for their satisfaction with the course is the possibility of collaborative learning in which they can discuss study topics in groups $(r=0.31)$. Student interaction is also highly correlated with both authentic learning $(r=0.62)$ and Teacher support $(r=0.53)$.

\section{Characteristics of the learning environment which predict students' motivation and course satisfaction}

The theory and empirical findings show that perceptions of learning environment positively influence motivation and course satisfaction. Since correlation only tests for interdependence of the variables, we were also interested in describing the predictive value of learning environment. Correlation analysis (presented in Table 3) showed many moderate to high connections between motivation and evaluation of learning environment. Since learning environment variables were mostly correlated to intrinsic goal-orientation, we were interested to determine which of these variables is the most important in predicting intrinsic motivation. Linear regression results are presented in Table 4.

Table 4. Regression Analysis Summary for Learning Environment Scales Predicting Intrinsic Goal-orientation

\begin{tabular}{lccc}
\hline Variable & B & SEB & $\beta$ \\
\hline Student interaction & .13 & .09 & .15 \\
Authentic learning & .46 & .11 & $.43^{* * *}$ \\
Teacher support & .07 & .09 & .07 \\
Autonomy & .19 & .07 & $.20^{* * *}$ \\
\hline
\end{tabular}

Note: $R^{2}=.43(N=118, p<.001)$.

$* * * p<.001$. 
The regression model is highly statistically significant and explains no less than $43 \%$ of the prediction of the dimensions of the learning environment of setting of intrinsic goals during learning $(F=21.34 ; p<0.001)$. As can be seen in Table 4, two characteristics of the learning environment statistically significant affect the Intrinsic goal-orientation: perception of learning as authentic, connected to practical problems $(\beta=0.43)$ and perceived autonomy during their study $(\beta=0.20)$. These results show that the more that students see their learning as relevant and valuable for their practical experiences, the more intrinsically motivated they feel. Intrinsic orientation was also emphasized with the possibilities of taking control over learning. This means that the more a teacher (according to the opinion of students) encourages and allows the autonomous decisions of students and provides them with opportunities to make co-decisions, the more the students perceive the studied topics as useful and the greater the probability they will be intrinsically motivated during their study.

Table 5 shows the importance of the factors that could predict student satisfaction. The regression model results have shown that all of the used variables explain in total $46 \%$ of the variance in predicting student course satisfaction $(F=11.91 ; p<0.001)$.

Table 5. Regression Analysis Summary for Motivation and Learning Environment Scales Predicting Course Satisfaction

\begin{tabular}{lccc}
\hline Variable & $\mathrm{B}$ & SEB & $\beta$ \\
\hline Self-efficacy & .03 & .09 & .03 \\
Intrinsic goal-orientation & .17 & .10 & .16 \\
Control beliefs & .10 & .09 & .10 \\
Extrinsic goal-orientation & -.07 & .07 & -.08 \\
Student interaction & -.15 & .09 & -.15 \\
Authentic learning & .41 & .12 & $.36^{* * *}$ \\
Teacher support & .37 & .09 & $.36^{* * *}$ \\
Autonomy & -.09 & .08 & -.08 \\
\hline
\end{tabular}

Note: $R^{2}=.46(N=118, p<.001)$.

${ }^{* * *} p<.001$.

Despite the numerous high correlations related to student satisfaction (shown in Table 3), we have established that greater satisfaction is significantly predicted by teacher support in the study process $(\beta=0.36)$, and the authenticity of learning $(\beta=0.36)$. No other predictive variable has proved to be 
statistically significant, although intrinsic goal-orientation is close to statistical significance $($ Sig. $=0.08)$. We can establish that the attention a teacher devotes to providing feedback to students' work, their encouragement and appropriate communication contribute to student enjoyment; the more a student perceives a teacher as doing so, the more the student is enjoying studying in a course.

\section{Discussion}

It the present study, we have examined the relationships among motivational and contextual aspects of studying in higher education. In sum, our results showed that perceived contextual dimensions mainly predict intrinsic goal-orientation, and they are the only statistically significant determinants of students' course satisfaction. Although intrinsic goal-orientation bivariate correlations were numerous, linear regression analysis revealed that is mainly correlated to authentic learning, teacher support, and perception of autonomy during learning.

\section{Learning environment's effect on motivation}

The results have shown that students who set themselves intrinsic goals have a greater sense of control of their learning and a feeling of self-efficacy. Furthermore, our study revealed that students who perceive their learning environment as a place that fosters autonomy and self-direction and find their education to be useful and relevant are more intrinsically motivated. The importance of collaborative learning and teacher support is also underscored. The results of the regression analysis reflect the findings from the correlation analysis and give even more significance to the real-life problems of the studied topics, and support in developing autonomy. The importance of the perceived authenticity of learning have also been proven in the correlation analysis. In this study, the interconnectedness of theoretical knowledge and practical application seems to be among the most important determinants of students' motivation for studying in higher education. These findings are also supported by the research that has been done on goal-orientations. Ames and Archer (1988) found that goals set on the classroom level also affect the goals set by individual students. Students who believed that their learning environment was performance-oriented and encouraging with regards to good grades and competition set themselves extrinsic goals also with learning. These results were later reinforced with further particularization of extrinsic goals in other studies (Church, Elliot, \& Gable, 2001; Gibbs \& Simpson, 2004; Gijbels \& Dochy, 2006; 
Roeser, Midgley, \& Urdan, 1996). On the one hand, researchers established that with stricter evaluation and reduced emphasis on the learning content, the possibility to follow extrinsic goals increased. On the other hand, those students who perceived the learning environment as oriented towards relevance and understanding set themselves intrinsic goals and reported a higher level of selfefficacy (Roeser, Midgley, \& Urdan, 1996). Our results also confirm a positive correlation of encouraging teacher support and cooperation between students on the development of intrinsic motivation and course satisfaction. Furthermore, our findings in relation to the importance of teacher support in the development of autonomy are supported by the study conducted by Green and colleagues (2004). They have established a positive relationship of the feeling of autonomy on the setting of intrinsic goals, higher self-efficacy, the use of strategies and better grades. Important factors also include encouraging cooperation among students. Students more frequently set themselves intrinsic goals in a learning environment that encourages cooperation and communication.

\section{Determinants of students' course satisfaction}

Our second research question was connected to the correlation and prediction of motivational and learning environment factors with students' satisfaction with education. Bivariate analysis showed several significant connections, especially with intrinsic goal-orientation, student interaction, authentic learning, and teacher support. However, regression analysis has proved that only authentic learning and (surprisingly) support for autonomy were statistically significant predictive variables. Both the time a teacher devotes to providing real-life examples to students and connecting theory to practice as well as enabling their autonomy in learning positively contributes to student enjoyment and satisfaction in the study program. This was confirmed by the research on the factors of enjoyment of education conducted by other authors (e.g. Lizzio, Wilson, \& Simons, 2002). Lizzio, Wilson, and Simons (2002) found that university students' perceptions of learning environment affect the learning performance, enjoyment of education, as well as development of key competences in learning outcomes, which directly and indirectly predict their attitude towards study.

In our opinion, the results of this study have practical implications for teachers because they provide a greater understanding about the different aspects of the learning environment and how those aspects predict student motivation and satisfaction. Our findings are consistent with other authors who have explored "authentic learning environments" (Herrington, Reeves, \& 
Oliver, 2014), and we can conclude that students will more likely develop intrinsic goal-orientation and enjoy studying when they view their course as relevant, interesting, and supportive of autonomy. Of course, these goals are difficult to achieve with the use of the top-down approach to teaching that is mostly controlled by the teacher. While some level of teacher-controlled didactic strategies are necessary for achieving his or her instructional goals, the results of our study suggest that a bottom-up approach that involves teaching strategies that increase student engagement and take into account their needs and interests could be more appropriate. We are well aware that increased intrinsic motivation is only one of the possible learning outcomes in higher education and that this is not always congruent with other, more cognitive outcomes. As some authors have suggested, this approach is not always effective (e.g., Segers, 1996). In the future, research studies should identify the learning outcomes that are important for evaluating the effectiveness of education (not only cognitive outcomes but also affective, social outcomes, etc.), and they should also recognize the strengths and weaknesses of the didactic strategies that arise from the constructivist learning environments.

\section{References}

Aldridge, J. M., Fraser, B. J., Bell, L., \& Dorman, J. (2012). Using a New Learning Environment Questionnaire for Reflection in Teacher Action Research. Journal of Science Teacher Education, 23(3), 259-29o. doi:10.1007/s10972-012-9268-1

Ames, C. (1992). Classrooms: Goals, structures, and student motivation. Journal of Educational Psychology, 84(3), 261-271. doi:10.1037/0022-0663.84.3.261

Ames, C., \& Archer, J. (1988). Achievement goals in the classroom: Students' learning strategies and motivation processes. Journal of Educational Psychology, 8o(3), 260-267. doi:10.1037/0o22-

0663.80 .3 .260

Archer, J. (1994). Achievement Goals as a Measure of Motivation in University Students.

Contemporary Educational Psychology, 19(4), 430-446. doi:10.1006/ceps.1994.1031

Austin, J. T., \& Vancouver, J. B. (1996). Goal constructs in psychology: Structure, process, and content. Psychological Bulletin, 120(3), 338-375. doi:10.1037/0033-2909.120.3.338

Bronfenbrenner, U. (1979). The ecology of human development: experiments by nature and design.

Cambridge, Mass.: Harvard University Press.

Church, M. A., Elliot, A. J., \& Gable, S. L. (2001). Perceptions of classroom environment, achievement goals, and achievement outcomes. Journal of Educational Psychology, 93(1), 43-54.

doi:10.1037/0022-0663.93.1.43

Cleveland, B., \& Fisher, K. (2014). The evaluation of physical learning environments: a critical review of the literature. Learning Environments Research, 17(1), 1-28. doi:10.1007/s10984-013-9149-3 
Cohen, J. (1988). Statistical power analysis for the behavioral sciences (2nd ed.). Hillsdale, N.J: L.

Erlbaum Associates.

Cunningham, D. J. (1992). Beyond educational psychology: Steps toward an educational semiotic.

Educational Psychology Review, 4(2), 165-194. doi:10.1007/BFo1322343

Deci, E. L., Koestner, R., \& Ryan, R. M. (2001). Extrinsic Rewards and Intrinsic Motivation in

Education: Reconsidered Once Again. Review of Educational Research, 71(1), 1-27.

Deci, E. L., \& Ryan, R. M. (1985). Intrinsic motivation and self-determination in human behavior. New

York: Plenum Press.

DeVellis, R. F. (2003). Scale development: theory and applications (2nd ed.). Thousand Oaks, Calif:

Sage Publications, Inc.

Dweck, C. S. (1985). Intrinsic motivation, perceived control, and self-evaluation maintenance: An achievement goal analysis. In R. Ames \& C. Ames (Eds.), Research on Motivation in Education: The classroom milieu. Academic Press.

Dweck, C. S. (1986). Motivational processes affecting learning. American Psychologist, 41(10), 1040-1048. doi: 10.1037/0003-066X.41.10.1040

Elliot, A. J., \& Church, M. A. (1997). A hierarchical model of approach and avoidance achievement motivation. Journal of Personality and Social Psychology, 72(1), 218-232. doi:10.1037/0o22-3514.72.1.218 Elliot, A. J., \& Harackiewicz, J. M. (1996). Approach and avoidance achievement goals and intrinsic motivation: A mediational analysis. Journal of Personality and Social Psychology, 7o(3), 461-475. doi:10.1037/0022-3514.70.3.461

Elliot, A. J., \& McGregor, H. A. (1999). Test anxiety and the hierarchical model of approach and avoidance achievement motivation. Journal of Personality and Social Psychology, 76(4), 628-644. doi:10.1037/0022-3514.76.4.628

Elliot, A. J., Murayama, K., \& Pekrun, R. (2011). A $3 \times 2$ achievement goal model. Journal of Educational Psychology, 103(3), 632-648. doi:10.1037/aoo23952

Elliott, E. S., \& Dweck, C. S. (1988). Goals: An approach to motivation and achievement. Journal of Personality and Social Psychology, 54(1), 5-12. doi:10.1037/0022-3514.54.1.5

Fraser, B. J. (1981). Test of Science Related Attitudes. Perth, Australia: Australian Council for Educational Research.

Fraser, B. J. (1989). Twenty years of classroom climate work: progress and prospect. Journal of Curriculum Studies, 21(4), 307-327. doi:10.1080/0022027890210402

Fraser, B. J., \& Fisher, D. L. (1982). Effects of Classroom Psychosocial Environment on Student Learning. British Journal of Educational Psychology, 52(3), 374-377. doi:10.1111/j.2044-8279.1982. tbo2525.x

Gibbs, G., \& Simpson, C. (2004). Conditions under Which Assessment Supports Students' Learning. Learning and Teaching in Higher Education, 1(1), 3-31.

Gijbels, D., \& Dochy, F. (2006). Students' assessment preferences and approaches to learning: can formative assessment make a difference? Educational Studies, 32(4), 399-409. doi:10.1080/03055690600850354 
Greene, B. A., Miller, R. B., Crowson, H. M., Duke, B. L., \& Akey, K. L. (2004). Predicting high school students' cognitive engagement and achievement: Contributions of classroom perceptions and motivation. Contemporary Educational Psychology, 29(4), 462-482. doi:10.1016/j. cedpsych.2004.01.006 Harackiewicz, J. M., Barron, K. E., Pintrich, P. R., Elliot, A. J., \& Thrash, T. M. (2002). Revision of achievement goal theory: Necessary and illuminating. Journal of Educational Psychology, 94(3), 638-645. doi:10.1037/0o22-0663.94.3.638

Herrington, J., Reeves, T. C., \& Oliver, R. (2014). Authentic Learning Environments. In J. M. Spector, M. D. Merrill, J. Elen, \& M. J. Bishop (Eds.), Handbook of Research on Educational Communications and Technology (pp. 401-412). Springer New York.

Kaplan, A., Gheen, M., \& Midgley, C. (2002). Classroom goal structure and student disruptive behaviour. The British Journal of Educational Psychology, 72(2), 191-211.

Kaplan, A., \& Maehr, M. L. (2007). The Contributions and Prospects of Goal Orientation Theory.

Educational Psychology Review, 19(2), 141-184. doi:10.1007/s10648-006-9012-5

Lizzio, A., Wilson, K., \& Simons, R. (2002). University Students' Perceptions of the Learning Environment and Academic Outcomes: Implications for theory and practice. Studies in Higher Education, 27(1), 27-52. doi:10.1080/03075070120099359

Locke, E. A., \& Latham, G. P. (1990). A Theory of Goal Setting \& Task Performance. Englewood Cliffs, NJ: Prentice-Hall, Inc.

Loyens, S. M. M., \& Gijbels, D. (2008). Understanding the effects of constructivist learning environments: introducing a multi-directional approach. Instructional Science, 36(5-6), 351-357. doi:10.1007/s11251-008-9059-4

Mažgon, J., \& Štefanc, D. (2012). Importance of the Various Characteristics of Educational Materials: Different Opinions, Different Perspectives. Turkish Online Journal of Educational Technology (TOJET), 11(3), 174-188.

Meece, J. L., Anderman, E. M., \& Anderman, L. H. (2006). Classroom Goal Structure, Student Motivation, and Academic Achievement. Annual Review of Psychology, 57(1), 487-503. doi:10.1146/ annurev.psych.56.091103.070258

Middleton, M. J., \& Midgley, C. (1997). Avoiding the demonstration of lack of ability: An underexplored aspect of goal theory. Journal of Educational Psychology, 89(4), 710-718. doi:10.1037/0022-0663.89.4.710

Midgley, C., Maehr, M. L., Hruda, L. Z., Anderman, E., Anderman, L., Freeman, K. E., \& Urdan, T. (200o). Manual for the Patterns of Adaptive Learning Scales. Michigan: University of Michigan. Moos, R. H. (1974). Systems for the assessment and classification of human environments: An overview. In R. H. Moos \& P. M. Insel (Eds.), Issues in Social Ecology: Human Milieus (pp. 5-29). Palo Alto, CA: National Press Books.

Moos, R. H. (2002). The Mystery of Human Context and Coping: An Unraveling of Clues. American Journal of Community Psychology, 30(1), 67-88. doi:10.1023/A:1014372101550

Nicholls, J. G. (1984). Achievement motivation: Conceptions of ability, subjective experience, task 
choice, and performance. Psychological Review, 91(3), 328-346. doi:10.1037/0033-295X.91.3.328 Nicholls, J. G., Patashnick, M., \& Nolen, S. B. (1985). Adolescents' theories of education. Journal of Educational Psychology, 77(6), 683-692. doi:10.1037/0022-0663.77.6.683

Nie, Y., \& Lau, S. (2010). Differential relations of constructivist and didactic instruction to students' cognition, motivation, and achievement. Learning and Instruction, 2o(5), 411-423. doi:10.1016/j. learninstruc.2009.04.002

Pajares, F. (1997). Current Directions in Self-efficacy Research. In M. L. Maehr \& P. R. Pintrich (Eds.), Advances in Motivation and Achievement (Vol. 10, pp. 1-49). Greenwich, Conn.: JAI Press.

Pintrich, P. R. (2000). Multiple goals, multiple pathways: The role of goal orientation in learning and achievement. Journal of Educational Psychology, 92(3), 544-555. doi:10.1037/0022-0663.92.3.544 Pintrich, P. R., \& De Groot (1990). Motivational and self-regulated learning components of classroom academic performance. Journal of Educational Psychology, 82(1), 33-40.

Pintrich, P. R., Smith, D. A. F., Garcia, T., \& McKeachie, W. J. (1991). A Manual for the Use of the Motivated Strategies for Learning Questionnaire (MSLQ) (No. Technical Report No. 91-8-004). Ann Arbor, MI: National Center for Research to Improve Postsecondary Teaching and Learning. Pintrich, P. R., \& Schunk, D. H. (2002). Motivation in education: Theory, research, and applications. Merrill Upper Saddle River, NJ.

Roeser, R. W., Midgley, C., \& Urdan, T. C. (1996). Perceptions of the school psychological environment and early adolescents' psychological and behavioral functioning in school: The mediating role of goals and belonging. Journal of Educational Psychology, 88(3), 408-422. doi:10.1037/0022-0663.88.3.408

Segers, M. (1996). Assessment in a Problem-Based Economics Curriculum. In M. Birenbaum \& F. Dochy (Eds.), Alternatives inAssessment of Achievements, Learning Processes and Prior Learning (pp. 201-226). Boston: Kluwer Academic Publishers.

Senko, C., Hulleman, C. S., \& Harackiewicz, J. M. (2011). Achievement Goal Theory at the Crossroads: Old Controversies, Current Challenges, and New Directions. Educational Psychologist, 46(1), 26-47. doi: 10.1080/00461520.2011.538646

Skaalvik, E. M. (1997). Self-enhancing and self-defeating ego orientation: Relations with task and avoidance orientation, achievement, self-perceptions, and anxiety. Journal of Educational Psychology, 89(1), 71-81. doi:10.1037/0022-0663.89.1.71

Smith, L., Sinclair, K. E., \& Chapman, E. S. (2002). Students' goals, self-efficacy, self-handicapping, and negative affective responses: An Australian senior school student study. Contemporary Educational Psychology, 27(3), 471-485.

Tabachnick, B. G., \& Fidell, L. S. (2013). Using multivariate statistics (6th ed.). Boston: Pearson Education.

Taylor, P. C., Fraser, B. J., \& Fisher, D. L. (1997). Monitoring constructivist classroom learning environments. International Journal of Educational Research, 27(4), 293-302. doi:10.1016/So8830355(97)90011-2

Urdan, T. (2004). Predictors of Academic Self-Handicapping and Achievement: Examining 
Achievement Goals, Classroom Goal Structures, and Culture. Journal of Educational Psychology, 96(2), 251. doi:10.1037/0022-0663.96.2.251

Urdan, T., \& Midgley, C. (2003). Changes in the perceived classroom goal structure and pattern of adaptive learning during early adolescence. Contemporary Educational Psychology, 28(4), 524-551. doi:10.1016/So361-476X(02)ooo6o-7

Urdan, T., Midgley, C., \& Anderman, E. M. (1998). The Role of Classroom Goal Structure in Students' Use of Self-Handicapping Strategies. American Educational Research Journal, 35(1), 101-122. doi:10.3102/00028312035001101

Walberg, H. J. (1969). Social environment as a mediator of classroom learning. Journal of Educational Psychology, 6o(6), 443-448. doi:10.1037/hoo28499

Walker, S. L., \& Fraser, B. J. (2005). Development and Validation of an Instrument for Assessing Distance Education Learning Environments in Higher Education: The Distance Education Learning Environments Survey (DELES). Learning Environments Research, 8(3), 289-308. doi:10.1007/s10984005-1568-3

Wang, M. C., Haertel, G. D., \& Walberg, H. J. (1990). What Influences Learning? A Content Analysis of Review Literature. The Journal of Educational Research, 84(1), 30-43.

Wolters, C. A., Yu, S. L., \& Pintrich, P. R. (1996). The relation between goal orientation and students' motivational beliefs and self-regulated learning. Learning and Individual Differences, 8(3), 211-238. doi:10.1016/S1041-6080(96)90015-1 


\section{Biographical note}

Danijela Makovec graduated at the Faculty of Arts, University of Ljubljana (UL). Currently she is a Ph.D. Student at the Department of Educational Sciences, Faculty of Arts, UL. She is working as a Teaching assistant for Didactics and Curriculum Studies at the Department of Educational Sciences, Faculty of Arts, UL. Her main activities and responsibilities are preparation and implementation of tutorials in Didactics, conducting of seminars in Didactics, scientific research in Didactics and Curriculum Studies. The research work of Danijela Makovec consists of studies into the teacher's role in planning and implementing instruction and didactic strategies, teacher's authority, the quality of university study and others.

MARKo RADOvan has a Ph.D. in psychology and is an assistant professor at the University of Ljubljana's Faculty of Arts. His research concentrates on characteristics of self-regulated learning and impact of learning environment on motivation to learn. He participated in several international research projects, most recent are "PIAAC (Programme for the International Assessment of Adult Competencies)", "Lifelong Learning 2010: Towards a Lifelong Learning Society in Europe" financed by European Commission's 6 Framework Programme and "Older Men as Active learners in the Community", coordinated by the University of Ljubljana. He organised or co-organized many international scientific meetings and is a co-editor of "Andragogic Perspectives", main Slovenian journal for adult education. 